\title{
Studies on drying and drying characteristics of tomato
}

\author{
K.A. MANE* AND S.V. GHODKE
}

MIT College of Food Technology, Rajbag Educational Complex, Loni Kalbhor, Haveli, PUNE (M.S.) INDIA

Email : kavita83.more@ rediffmail.com; sujataw29@gmail.com

\section{SUMMARY :}

Dehydrated tomato products (pieces, slices) were prepared to study the effect of drying time on moisture content and drying rate. The tomato pieces and slices $(5,10,15 \mathrm{~mm}$ thick) were treated with citric acid $(0.1 \%)$ and $\mathrm{NaCl}(2 \%)$ and further dried in tray dryer $\left(55 \pm 2{ }^{\circ} \mathrm{C}\right)$. Another sample was prepared by removing peel and cutting into pieces further dried in tray dryer at $55 \pm 2{ }^{\circ} \mathrm{C}$. Drying curves were plotted and drying behaviour was studied. Total drying time of 12 to $28 \mathrm{~h}$ was required to dry the material to about 7 to 8.1 per cent, d.b. moisture content. Drying rate varied between 919.48 to $0.84 \mathrm{~g} / 100 \mathrm{~g}$ for all tomato products. Drying of tomato pieces/slices was followed in the falling rate period. Dehydration ratio varied between 15.5:1 and16.9:1 for all dehydrated tomato products.

KEY WORDS : Tomato, Drying, Drying rate, Drying curves, Moisture content

How to cite this paper: Mane, K.A. and Ghodke, S.V. (2016). Studies on drying and drying characteristics of tomato. Internat. J. Proc. \& Post Harvest Technol., 7 (2) : 179-183. DOI: 10.15740/HAS/IJPPHT/7.2/179183. 